Ann. Biol. anim. Bioch. Biophys., 1978, 18 (4), 767-771.

\title{
Interaction of salmon gonadotropin subunits : spectroscopic studies
}

\author{
par R. SALESSE, J. GARNIER, B. BRETON *
}

Laboratoire de Biochimie physique, I. N. R. A. Département de Biochimie et de Biophysique, Université de Paris-Sud 91405 Orsay Cedex

* Laboraioire de Physiologie des Poissons, I. N. R. A. 78350 Jouy en Josas, France

Summary. Pituitary gonadotropins of female and male pacific salmon Oncorhynchus tshawytscha were prepared separately. The two preparations exhibited different sedimentation coefficients (2.8 and 2.3, respectively) but similar circular dichroism spectra indicative of low $\alpha$ helix and high $\beta$ sheet contents. Both hormones gave a difference spectrum $\left(1750 \mathrm{M}^{-1} \mathrm{~cm}^{-1}\right.$ at $\left.287 \mathrm{~nm}\right)$ characteristic of perturbed tyrosine and phenylalanine residues when dissociated at acid $\mathrm{pH}$. These results suggest that fish and mammal gonadotropins exhibit the same general folding of their polypeptide chains and undergo the same conformational transition when their subunits associate; however, fish gonadotropin subunits reassociate at considerably faster rates.

\section{Introduction.}

The presence of two distinct gonadotropins in fish is still an open and interesting question. A single gonadotropin having both lutropin and follitropin activities was found in carp (Billard ef al., 1970 ; Burzawa-Gérard, 1971, 1974a ; Sundararaj ef al., 1976) and in salmon (Donaldson ef al., 1972), although physicochemical, biological or immunological evidence for two distinct gonadotropins has been presented (Idler ef al., 1975a; Pierce ef al., 1976).

As those of mammalian origin, fish gonadotropins are composed of two dissimilar subunits (Donaldson et al., 1972 ; Burzawa-Gérard, 1974b ; Burzawa-Gérard ef al., 1975) which can be dissociated in acid condition with loss of biological activity. This activity loss in mammalian hormones is accompanied by a specific conformational change of the subunits which is association-dependent (see review in Garnier, 1978). From experiments reported below, it is shown that two gonadotropin preparations, one from female salmon $\left(s \mathrm{GTH}_{1}\right)$, the other from male salmon (s $\mathrm{GTH}_{2}$ ), also undergo the same reversible conformational transition during the associationdissociation process of their two subunits. 


\section{Material and methods.}

The gonadotropins were prepared from separate female and male pituitary glands of pacific salmon Oncorhynchus tshawytscha, according to Idler ef al. (1975a). Assayed in vitro for trout oocyte maturation (Jalabert et al., 1974), both preparations exhibited the same potency and were two times more active than a sample obtained from Idler and prepared according to his method (Idler ef al., 1975b).

Protein concentrations were determined by a Lowry assay with bovine serum albumin as standard.

Ultracentrifuge experiments were carried out in a Spinco Beckman ultracentrifuge model $E$.

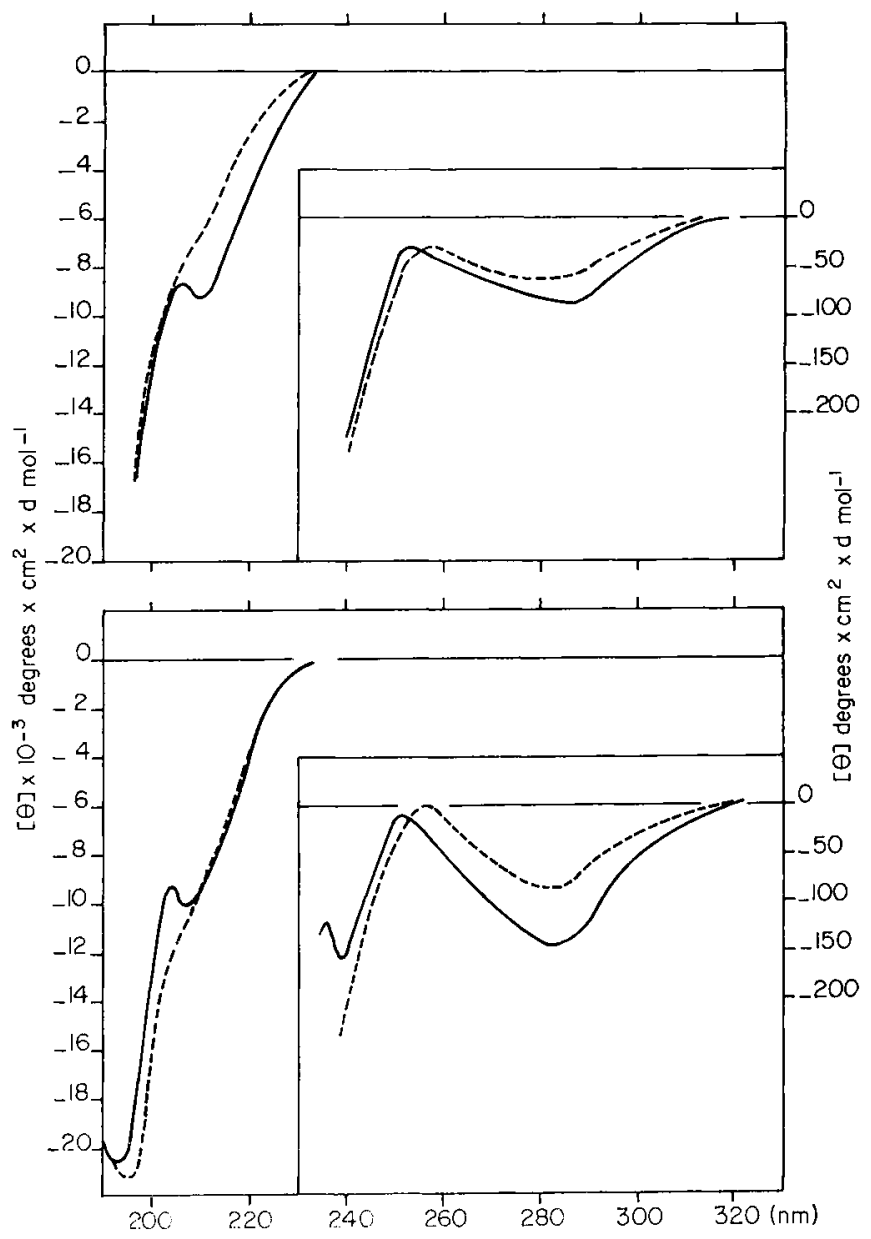

FIG. 1. - CD spectra of $s \mathrm{GTH}_{1}$ (bottom) and $s \mathrm{GTH}_{2}$ (above) assuming a mean molecular weight per residue of 141. 
Circular dichroism spectra were recorded with a Jouan Dichrograph III ; light paths were 0.5 to $0.01 \mathrm{~cm}$. Mean molecular weight per residue was assumed as 141 .

Optical densities and U. V. difference spectra were recorded in a Cary 118 spectrophotometer with a $1 \mathrm{~cm}$ light path cuvette in a thermostated holder. Kinetics of dissociation and reassociation of hormones were followed at $287 \mathrm{~nm}$.

\section{Results and discussion.}

The two preparations were found to differ essentially by their sedimentation coefficient $\left(\mathrm{S}_{20}, \mathrm{w}\right)$ of 2.8 for $\mathrm{s} \mathrm{GTH}_{1}(0.5 \mathrm{mg} / \mathrm{ml})$ and 2.3 for $\mathrm{s} \mathrm{GTH}_{2}(0.7 \mathrm{mg} / \mathrm{ml})$ at neutral $\mathrm{pH}, 0.1 \mathrm{M} \mathrm{NaCl}$. Both exhibited the same absorbance spectra with a maximum at 275-276 $\mathrm{nm}$ characteristic of tyrosine residue with no tryptophane contribution.

They had similar circular dichroism (CD) spectra (fig. 1) with minima at $280 \mathrm{~nm}$, $210 \mathrm{~nm}\left(\mathrm{~s} \mathrm{GTH}_{2}\right)$ or $208 \mathrm{~nm}(\mathrm{~s} \mathrm{GTH})$ and $193 \mathrm{~nm}$; $\mathrm{GTH}_{1}$ had another small band at $234 \mathrm{~nm}$. All these bands were already reported for mammalian gonadotropins and they are indicative of low $\alpha$ helix and high $\beta$ sheet contents. These CD spectra suggest that the general gonadotropin folding has been conserved through evolution from fish to mammal.

Other interesting common features are the blue shift of the far U. V. CD, the decrease of the CD band at $280 \mathrm{~nm}$ (fig. 1) and the appearence of difference spectra $\left(1750 \mathrm{M}^{-1} \mathrm{~cm}^{-1}\right.$ at $\left.287 \mathrm{~nm}\right)$ characteristic of perturbed tyrosine and phenylalanine residues (fig. 2) when the hormones are dissociated at acid $\mathrm{pH}$. By raising the $\mathrm{pH}$ again to neutral, the two subunits reassociated with recovery of most of the native $C D$ and loss of the difference spectrum. This suggests that salmon gonadotropins undergo the same conformational transition as mammalian gonadotropins when their two subunits associate.



FIG. 2. - UV difference spectrum of $s-G_{T H}$ upon dissociation at $\mathrm{pH} 2.2$ Reference : s-GTH ${ }_{1}$ at $\mathrm{pH} 5.6$. 
Association-dissociation processes were followed with time (fig. 3) ; contrary to mammalian hormones, they were found to be much more rapid processes. For example, reassociation of $s G T H$ at neutral $\mathrm{pH}$ from acid $\mathrm{pH}$ at $37^{\circ} \mathrm{C}$ was 5 to 10 times faster than association of o-lutropin subunits or 20 to 50 times faster than h-choriogonadotropin reassociation (Pernollet at al., 1976).

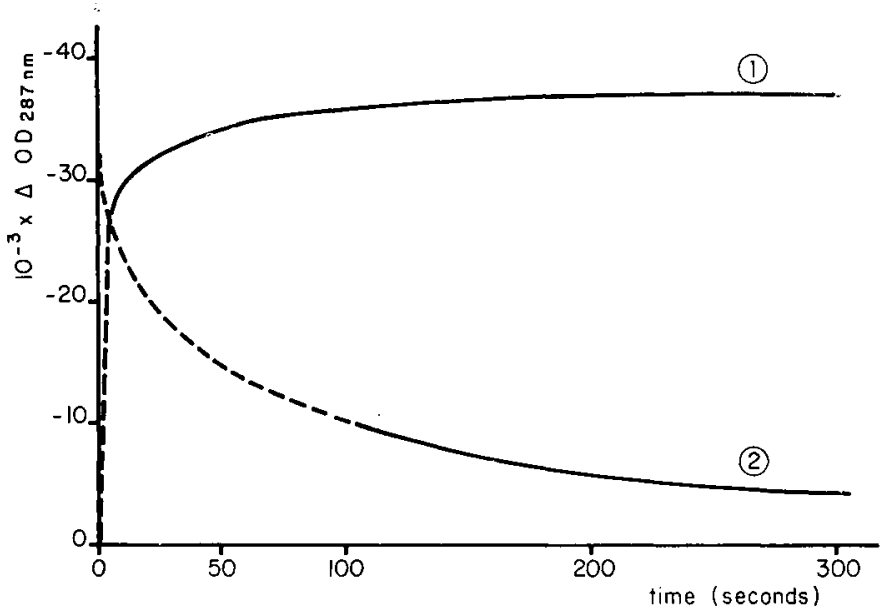

FIG. 3. - Change with fime of the absorbance at $287 \mathrm{~nm}$ of s-GTH during dissociation of the subunits at $\mathrm{pH} 2$ (curve 1) and re-association at $\mathrm{pH} 6.4$ (curve 2). Temperature $37^{\circ} \mathrm{C}, 0.1 \mathrm{M} \mathrm{NaCl}$. Dashed parts correspond to extrapolated absorbance change to zero time.

These observations strengthen the hypothesis that subunit association and subsequent conformational change are necessary steps in vivo for the formation of active gonadotropin.

Symposium sur la Reproduction des Poissons Paimpont, France, 19-21 septembre 1977.

Aknowledgments. - We are very grateful to Dr. Idler for providing us with a sample of salmon gonadotropin for bioassays.

Résumé. A partir d'hypophyses du saumon Oncorhynchus tshowytscha femelle et mâle deux préparations de gonadotropine ont été obtenues. Elles ne diffèrent que par leur coefficient de sédimentation respectivement 2,8 et 2,3 . Leurs spectres de dichroïsme circulaire sont semblables et indiquent une faible teneur en hélice $\alpha$ et une forte teneur en structure $\beta$. $\mathrm{A} \mathrm{pH}$ acide, ces deux hormones se dissocient en leurs sous-unités, donnant naissance à un spectre de différence $\left(1750 \mathrm{M}^{-1} \mathrm{~cm}^{-1}\right.$ à $\left.287 \mathrm{~nm}\right)$ caractéristique de résidus tyrosines et phénylalanines perturbées. Ces résultats suggèrent que les gonadotropines de poisson et de mammifère présentent la même conformation générale de leurs chaînes polypeptidiques et qu'elles subissent la même transition conformationnelle quand leurs sous-unités s'associent à la différence que les sous-unités de gonadotropine de poisson s'associent à des vitesses beaucoup plus grandes. 


\section{References}

BILLARD R., BURZAWA-GÉRARD E., BRETON B., 1970. Regénération de la spermatogenèse du cyprin hypophysectomisé (Carassius auratus) par un facteur gonadotrope hautement purifié de carpe. C. R. Acad. Sci. Paris, Sér. D, 271, 1896-1899.

BURZAWA-GÉRARD E., 1971. Purification d'une hormone gonadotrope hypophysaire de poisson téléostéen, la carpe (Cyprinus carpio L.) Biochimie, 53, 545-552.

BURZAWA-GÉRARD E., 1974a. Etude biologique et biochimique de l'hormone gonadotrope d'un poisson téléostéen, la carpe (Cyprinus carpio L.). Mém. Mus. nat. Hist. nat., sér. A, Zoologie, 86, 1 -77.

BURZAWA-GÉRARD E., 1974b. Séparation et réassociation des sous-unités de l'hormone gonadotrope d'un poisson téléostéen, la carpe (Cyprinus carpio L.). C. R. Acad. Sci. Paris, sér. D, 279, $1681-1684$.

BURZAWA-GÉRARD E., GONCHAROV B. F., FONTAINE Y. A., 1975. L'hormone gonadotrope hypophysaire d'un poisson chondrostéen, l'esturgeon (Acipenser stellatus). II. Propriétés biochimiques. Gen. comp. Endocrinol., 27, 296-304.

DONALDSON E. M., YAMAZAKI F., DYE H. M., PHILLEO N. W., 1972. Preparation of gonadotropin from salmon (Oncorhynchus tshawytscha) pituitary glands. Gen. comp. Endocrinol., 18, 469-481.

GARNIER J., 1978. Molecular aspects of the subunit assembly of the glycoprotein hormones. In McKERNS K. W., The gonadotropins : structure and function, Plenum Publ. Co., New York (in press).

IDLER D. R., BAZAR L. S., HWANG S. J., 1975a. Fish gonadotropin(s). IIt. Evidence for more than one gonadotropin in chum salmon pituitary glands. Endocr. Res. Commun., 2, 237-249.

IDLER D. R., BAZAR L. S., HWANG S. J., 1975b. Fish gonadotropin(s). II. Isolation of gonadotropin(s) from chum salmon pituitary glands using affinity chromatography. Endocr. Res. Commun., 2, 215-235.

JALABERT B., BRETON B., BILLARD R., 1974. Dosage biologique des hormones gonadotropes de poissons par le test de maturation in vitro des ovocytes de truite. Ann. Biol. anim. Bioch. Biophys., 14, 217-228.

PERNOLLET J.-C., GARNIER J., PIERCE J. G., SALESSE R., 1976. In vitro activation of glycoprotein hormones. Hybridization of subunits from thyrotropin, lutropin and human choriogonadotropin. Biochim. biophys. Acta, 446, 262-276.

PIERCE J. G., FAITH M. R., DONALDSON E. M., 1976. Antibodies to reduced S-carboxymethylated alpha subunit of bovine luteinizing hormone and their application to study the purification of gonadotropin from salmon (Oncorhynchus tshawytscha) pituitary glands. Gen. comp. Endocrinol., 30, 47-60.

SUNDARARAJ B. I., NAYYAR S. K., BURZAWA-GÉRARD E., FONTAINE Y. A., 1976. Effect of carp gonadotropin on ovarian mainfenance maturation and ovulation in hypophysectomized catfish, Heferopneustes fossilis (Bloch). Gen. comp. Endocrinal., 30, 472-476. 